\title{
Assessing Psychological Violence and Harassment at Work: Re- liability and Validity of the Japanese Version of the Inventory of Violence and Psychological Harassment (IVAPT) Comparing NAQ-R and LIPT
}

\author{
Manuel Pando Moreno ${ }^{1 *}$, Carolina Aranda Beltrán ${ }^{1}$, Kanami Tsuno $^{2,3}$, \\ Akiomi INOUE ${ }^{4}$ and Norito KAWAKAMI ${ }^{2 *}$ \\ ${ }^{1}$ Institute of Research on Occupational Health, University of Guadalajara, Mexico, ${ }^{2}$ Department of Mental Health, \\ Graduate School of Medicine, The University of Tokyo, Japan, ${ }^{3}$ Japan Society for the Promotion of Science, Japan \\ and ${ }^{4}$ Department of Mental Health, Institute of Industrial Ecological Sciences, University of Occupational and \\ Environmental Health, Japan
}

\begin{abstract}
Assessing Psychological Violence and Harassment at Work: Reliability and Validity of the Japanese Version of the Inventory of Violence and Psychological Harassment (IVAPT) Comparing NAQ-R and LIPT: Manuel PANDo MoReno, et al. Institute of Research on Occupational Health, University of Guadalajara, Mexico-Objective: The objective of this study was to examine reliability and validity of the Japanese version of the Inventory of Violence and Psychological Harassment (IVAPT) (Pando, 2006), a 22-item measure of psychological harassment at work and presence and intensity of psychological violence widely used in Latin American countries. Methods: The IVAPT was translated into Japanese, and the translation was amended through a small pretest and a back-translation and finalized. A total of 1,810 out of 4,072 civil servants completed a questionnaire including the IVAPT. Results: Cronbach's alpha of the scale was 0.97 for psychological violence and 0.94 for psychological harassment at work. An exploratory factor analysis showed that the first factor explained $64.5 \%$ of the total variance. Data did not well fit to previously reported one- or three-factor structures. Psychological violence and harassment at work were more frequent among older respondents. Intensity of psychological violence was well concordant with other scales of workplace bullying, i.e., Leymann Inventory of Psychological
\end{abstract}

Received Sept 29, 2012; Accepted Jan 11, 2013

Published online in J-STAGE Feb 15, 2013

Correspondence to: M. Pando Moreno, President and Vice Director of the International Institute of Social, Psychological, and Occupational Health Research (IIISASO) and Director of the Institute for Research on Occupational Health (IISO), University of Guadalajara, Mexico (e-mail: manolop777@yahoo.com.mx)

* Equal contribution.
Terrorization (LIPT) and Negative Acts QuestionnaireRevised (NAQ-R), and psychological harassment at work was well concordant with the NAQ-R. Conclusions: The Japanese version of the IVAPT showed high internal consistency reliability. While the first factor explained a large proportion of the variance, the IVAPT seems to have a unique factor structure in the Japanese sample. Concurrent validity of the IVAPT was supported by the comparison with the other scales.

(J Occup Health 2013; 55: 108-119)

Key words: Inventory of Violence and Psychological Harassment (IVAPT), Negative Acts Questionnaire, Occupational health, Psychological harassment at work, Validation, Workplace bullying

Psychological harassment at work, also called as mobbing or workplace bullying, a form of psychological abuse that occurs in the workplace, remained invisible for a long time ${ }^{1)}$. Since psychological harassment started to receive attention in 1980s, it became a major topic of research in the field of organizational psychology in the $1990 \mathrm{~s}^{2}$. While there are various definitions of psychological harassment, they commonly have four elements: 1) there is a manifestation of psychologically aggressive behaviors; 2) they are presented repeatedly and long-lasting; 3) they are carried out deliberately or unconsciously but clearly cause damage to the victims; and 4) there is an imbalance of power between parties. Thus, the concept of psychological harassment in the present study is very similar to the one presented by Moreno-Jiméneg et $a l .{ }^{3)}$ who conceived "the psychological harassment as continuing attitudes and hostile behavior, directed in a systematic way by one or several individuals against 
another, in order to discredit and humiliate, isolate, and ultimately cause abandonment of the job," or that presented by Einarsen et al. ${ }^{2}$, who described it as "harassing, offending, or socially excluding someone or negatively affecting someone's work."

A report from the International Labour Organization (ILO) pointed out that at least $10 \%$ of workers were being exposed to psychological harassment or bullying ${ }^{4}$. According to the fifth European Working Conditions Survey ${ }^{5)}$ published by the European Foundation for the Improvement of Living and Working Conditions (Eurofound), 4\% of workers report having been exposed to bullying or harassment during the previous year. In Spain, the latest report from Eurofound estimated that around 800 thousand people were suffering from psychological harassment in their current jobs ${ }^{6}$. Various studies have shown that psychological harassment is strongly related to a wide range of health problems, such as sleep disorders, anxiety, psychosomatic problems, irritability, and depression or posttraumatic stress as the most serious outcome ${ }^{7-12)}$. Other common side effects of the condition of the mobbing are apathy and feelings of helplessness and hopelessness ${ }^{13,14)}$. These consequences have been converted into bullying in a topic of great public interest that has led to a growing number of investigations.

Two major scales have been developed to measure psychological harassment at work and are widely used in Europe and other English-speaking countries. The first observations of harassment at work came from a clinical work of Swedish researcher Heinz Leymann, who developed the Leymann Inventory of Psychological Terrorization (LIPT) ${ }^{3,15)}$. The LIPT evaluates the 12-month prevalence of exposure of 45 forms of bullying. The other instrument is the Negative Acts Questionnaire (NAQ) and its successor, the Negative Acts Questionnaire-Revised (NAQ-R), developed by Norwegian researchers Einarsen and Raknes ${ }^{16)}$. It consists of 22 items and evaluates the six-month prevalence of workplace bullying. Prevalence of psychological harassment at work (workplace bullying) has been reported from 3.5\% in Sweden $^{14)}$, to $51 \%$ in Spain $^{17)}$ when using the LIPT and from 8 to $15 \%$ when using the NAQ-R ${ }^{18,19)}$ among European countries. These two scales have been also translated into the Japanese language and used in studies of prevalence and psychological impact of psychological harassment ${ }^{20)}$, with a prevalence of $4 \%$ for the LIPT and $9 \%$ for the NAQ-R.

On the other hand, among Latin American countries and Spain, an instrument called the Inventory of Violence and Psychological Harassment (IVAPT) was developed and widely used. The prevalence of psychological harassment at work using the IVAPT has been reported to be $8.5 \%$ in Mexico, $17.9 \%$ in Chile, $9.4 \%$ in Spain, $19.4 \%$ in Costa Rica, $3.5 \%$ in Bolivia, $6.1 \%$ in Ecuador, and $7.5 \%$ in $\mathrm{Cuba}^{13,21-25)}$. These prevalences are similar to the prevalences reported from Europe using the $\mathrm{NAQ}^{19}$. The IVAPT has several unique features compared with the LIPT and NAQ/NAQ-R. First, the behaviors included in the IVAPT were from Latin American countries, such as Mexico and Spain, which are known as a more hierarchy- and collectivism-oriented countries compared with Northern and Middle European countries. The IVAPT may be more sensitive to measuring psychological harassment at work among hierarchy- and collectivism-oriented countries, such as Japan. Second, the IVAPT was designed to measure not only psychological harassment at work, but also psychological violence. In many organizations, psychological aggression is used as a mode of communication in some countries ${ }^{3)}$. For instance, psychological aggression is used as an administrative procedure to give orders or to request someone to do an action, but without the intent to produce damage. Distinguished from psychological harassment at work, psychological violence in the workplace could be called "generic violence", and applied to all workers, with less psychological impact than mobbing ${ }^{21)}$. The IVAPT measures this aspect of psychological violence, separately from psychological harassment. It is important to assess these two aspects of psychologically adverse experiences separately in order to study their differential impacts and also to take appropriate specific action against them ${ }^{26,27)}$. However, the IVAPT has not been translated into any Asian language including Japanese.

The objective of this study was to examine reliability and validity of the newly developed Japanese version of the IVAPT in the working population of Japan. In this study, we examined internal consistency reliability and factor-based validity of the Japanese version of the IVAPT. We also compared psychological violence and psychological harassment at work measured by the IVAPT with workplace bullying measured by the LIPT and NAQ-R to examine the concurrent validity.

\section{Method}

\section{Participants}

This study was based on data from a previous cross-sectional study of employees of the public institutions in the Kanto region in Japan in March $2009^{20)}$. In total, 4,072 anonymous questionnaires on workplace harassment and demographic characteristics were distributed to employees in the public sector via seven labor unions, with a letter describing aims and procedures of the study, particularly assuring that the 
survey was anonymous and that no individual would be identified in analyzing and reporting the data. A total of 2,194 were returned sealed in an envelope, providing a response rate of $46.7 \%$. The number of respondents in this study was considered enough for analyzing a factor structure of the IVAPT. The study procedure was approved by the Ethics Committees of the Graduate School of Medicine, The University of Tokyo.

\section{Measures}

\section{1) IVAPT}

This instrument consists of 22 items with two sets of response options (see Appendix). First, respondents were asked to answer the frequency of their experience of each item in the column (A) using five-point Likert-type options: "never" (0), "almost never" (1), "sometimes" (2), "frequently" (3), and "very frequently" (4). Second, respondents were asked to report the relative frequency of experiencing each item compared with their colleagues in the column (B), using three response options: less than my colleagues (1), same as my colleagues (2), and more than my colleagues (3). In addition, an additional final question asked whether the behaviors assessed have been produced by superiors, colleagues, or subordinates at work, which allows us to have reports of the directionality of the behaviors (mobbing ascending, collateral, or descending). Previous studies showed that the IVAPT had an acceptable level of internal consistency (Cronbach's alpha coefficients of 0.91-0.95) and factorial validity (53-66\% of variance explained by the first factor) in Mexico, Spain, and Chile ${ }^{13,21,22)}$.

The instructions, items and response options of the IVAPT were first translated from the English version into Japanese by a professional translator. Then we tested this first translated version with a group of nine occupational health staff (occupational physicians, occupational health nurses, and clinical psychologists) in Japan to receive their feedback, and revised the translation accordingly. Then we back-translated the revised version into Spanish, which was then reviewed by the original author and also discussed for further refinement between Japanese and Mexican authors. This led to a small amendment to finalize the Japanese version of the IVAPT (e.g., the order of the response options in the column (A) was reversed).

The IVAPT provides three indicators of psychological violence and harassment at work, i.e., psychological harassment at work and the presence and intensity of psychological violence at work. The presence of psychological violence was defined based on the number of items for which the frequency was other than "never" (i.e., from "almost never" to "very frequent") and classified into high (5+), medium (1-4) and none (0). The intensity of psychological violence was defined as based on the total score of the frequency (0-88) and classified into high (45+), medium (23-44), low (1-22), and none (0). Psychological harassment at work was defined based on the number of items that a respondent reported experiencing more than the rest of his/her colleagues, and classified into high (8+), medium (4-7), and none (0-3). Those classified as high or medium were considered to be experiencing psychological harassment at work. For interpretation, the presence of psychological violence at work was defined based on conflict situations at work that, when not resolved, can be habitual behavior. The intensity of psychological violence at work was defined based on situations with sustained generic violence at work that can be received by all workers at a workplace. When these behaviors intentionally target a single worker, which is determined based on whether a particular worker is targeted more than his/ her colleagues in the IVAPT, they can be considered to be psychological harassment at work.

Unfortunately, many items in column (B) were missing responses, particularly when the column (A) response was "never" (0). Thus, in this study, we assigned "same as my colleagues (2)" for the column (B) response in this case to reduce the number of missing responses.

2) Other scales of workplace harassment

The respondents were also asked to complete the Japanese versions of the NAQ- ${ }^{20,28)}$ and $\operatorname{LIPT}^{7,20)}$. The NAQ-R is a 22-item scale measuring how often during the past six months respondents have been subjected to negative acts ("never", "now and then", "monthly", "weekly", and "daily"). Cronbach's alpha coefficients of the internal consistency reliability of the NAQ-R were high (0.91-0.95), and the factorbased validity was confirmed among Japanese work$\mathrm{ers}^{20)}$. Those who responded that they had any of the 22 items weekly or daily were defined as having NAQ-R workplace bullying. The LIPT has 45 items, measuring the experience of bullying within the previous 12 months, with two response options (no or yes), as well as two additional questions on the frequency and duration of bullying. The Cronbach's alpha coefficients were high (0.93-0.95) among workers in Japan ${ }^{20)}$. According to Leymann's definition, those who reported (1) exposure to at least one of 45 bullying behaviors within the previous 12 months, (2) weekly or more, and (3) for six months or longer were defined victims of bullying. Unfortunately, there were a large number of respondents who had missing responses on these scales. In the comparison between the IVAPT and these scales, the number of respondents was smaller than that of the total sample and varied because of the pairwise deletion of respondents 
with missing responses.

3) Other covariates

Demographic variables, such as sex, age, occupation, and duration of employment, were also asked in the questionnaire.

\section{Statistical analysis}

Average responses for column (A) responses (frequency) and column (B) responses (more than the colleagues) were calculated for the total sample. Cronbach's alpha coefficient of internal consistency reliability was calculated for column (A) responses and column (B) responses for the total sample, men and women.

The column (A) responses were subjected to a factor analysis using principal component analysis with varimax rotation. Since previous studies reported a one-factor structure and three-factor structure of the IVAPT $^{13)}$, we predetermined the number of factors as three. It was assumed to consist of the following factors: (1) manipulation to induce the punishment (MIC), which expresses the handling of situations in work to lead to errors or faults that are worthy of punishment (item \#4, 7, 11-15, and 17-20); (2) damage to public image (DPI), which are behaviors that affect socially and deteriorate the image of the person concerned (item \#1-3, 8, and 16); and (3) obstacles to work performance (ODL), which include actions to restrict initiative, success and future professional achievement of the person (item \#5, 6, 9, 10, 21 , and 22). We also conducted a series of confirmatory factor analyses to test the one-factor structure and a three-factor structure ${ }^{13)}$.

Three indicators based on the IVAPT, i.e., psychological harassment at work and the presence and intensity of psychological violence, were calculated and compared between men and women and among the three age groups (chi-square test). These indicators were compared with workplace bullying defined based on the LIPT and NAQ-R (chi-square test and kappa coefficient). These statistical analyses were conducted by using IBM SPSS ver. 16 and SAS ver. 9.3 .

\section{Results}

\section{Demographic characteristics}

A total of 1,810 respondents (909 men and 901 women) out of 2,194 initial respondents filled in all questions including sex, age, and the IVAPT. The average (standard deviation, SD) age of workers was 42.2 (10.2) years, with a range from 20 to 63 years. Men accounted for $51.5 \%$ of respondents, while women accounted for $48.5 \%$ of respondents. The average duration (SD) of employment was 10.9 (11.0) years. Respondents included 131 managers,
845 nonmanual workers (clerks), 285 manual workers (food service, garbage collection, etc.), 464 medical and welfare service workers, and 85 others/unknown. A total of 1,747 were full-time workers, 46 were parttime workers, and 17 were employed for a temporary job.

\section{Item score distributions}

The score of frequency asked in the column (A) was greater for item \#18, "New jobs are unceasingly assigned to me"; \#9, "My work is devalued and they never recognize my doing something well"; \#1, "I receive attacks on my reputation"; and \#2, "They have tried to humiliate me or to make a fool of me in public" (Table 1). Frequency of being reported more than colleagues was also greater for these items. On the other hand, item \#7, "Work situations are manipulated to make me commit errors and later accuse me of negligence or of being a bad worker," and \#19, "The work or activities given to me require more experience than that which I possess, and they are assigned to me with the intention of discrediting me," were least frequent. The average (SD) number of items for which column (A) was more than "never" was 4.6 (7.5). The average (SD) total score of frequency in column (A) was 6.5 (10.9). The average (SD) number of items in column (B) that respondents reported experiencing more than their colleagues was 0.7 (2.6).

\section{Cronbach's alpha}

The Cronbach's alpha coefficients of internal consistency reliability for responses concerning the frequency in column (A) were 0.97 in the total sample, 0.94 for men, and 0.97 for women. The Cronbach's alpha coefficients for responses concerning experiencing more than one's colleagues were 0.94 for the total sample, 0.95 for men and 0.92 for women when using a dichotomous response, i.e., no (less then or same as one's colleagues $=0$ ) and yes (more than one's colleagues $=1$ ).

\section{Factor-based validity}

In an exploratory factor analysis, eigenvalues (and the total variance explained) were 14.20 for the first factor $(64.5 \%), 1.04$ for the second factor $(4.7 \%)$, and 0.84 for the third factor $(3.8 \%)$. A threefactor solution after varimax rotation indicated that 13 items (\#5, 6, 7, 12-17, and 19-22) were loaded on factor 1 , most of which addressed manipulation of work situation to make work difficult (Table 2). Seven other items (\#1-3 and 8-11) were loaded on factor 2, which mostly addressed attacks on public image. The remaining two items (\#4 and 18) were loaded on factor 3, which addressed assignment of work demands, such as ones with a short deadline or 
Table 1. Average item scores (with standard deviation [SD]) for frequency and proportions of those who reported experiences more than their colleagues of the Inventory of Violence and Psychological Harassment (IVAPT) among the total respondents $(\mathrm{n}=1,810)$ from employees of civil servant offices in Japan

\begin{tabular}{|c|c|c|c|}
\hline \multirow[b]{2}{*}{ Item } & \multicolumn{2}{|c|}{$\begin{array}{l}\text { Column }(\mathrm{A}) \text { - } \\
\text { Frequency }^{\dagger}\end{array}$} & \multirow{2}{*}{$\begin{array}{c}\text { Column (B) } \\
\text {-more than } \\
\text { colleagues } \\
(\%)\end{array}$} \\
\hline & Average & $\mathrm{SD}$ & \\
\hline 1. I receive attacks on my reputation. & 0.36 & 0.65 & 4.5 \\
\hline 2. They have tried to humiliate me or to make a fool of me in public. & 0.36 & 0.66 & 4.4 \\
\hline 3. I receive mockery, slander or public defamation. & 0.31 & 0.62 & 3.4 \\
\hline $\begin{array}{l}\text { 4. They assign me work or projects with such short deadlines that they are impossible to ful- } \\
\text { fill. }\end{array}$ & 0.34 & 0.64 & 3.9 \\
\hline 5. I am ignored or excluded from work meetings or from decision-making. & 0.34 & 0.68 & 4.3 \\
\hline 6. I am denied information that is important and necessary for me to carry out my work. & 0.27 & 0.60 & 2.9 \\
\hline $\begin{array}{l}\text { 7. Work situations are manipulated to make me commit errors and later accuse me of negli- } \\
\text { gence or of being a bad worker. }\end{array}$ & 0.15 & 0.43 & 1.4 \\
\hline 8. Malicious or slanderous rumors are spread by the company about me. & 0.23 & 0.56 & 2.8 \\
\hline 9. My work is devalued and they never recognize my doing something well. & 0.40 & 0.75 & 4.6 \\
\hline $\begin{array}{l}\text { 10. My successes at work are ignored and maliciously attributed to other people or to foreign } \\
\text { elements such as coincidence, luck, the market situation, etc. }\end{array}$ & 0.25 & 0.60 & 2.7 \\
\hline $\begin{array}{l}\text { 11. My errors or small faults are punished much more drastically than the rest of my col- } \\
\text { leagues. }\end{array}$ & 0.34 & 0.67 & 4.0 \\
\hline $\begin{array}{l}\text { 12. The possibilities of communicating with colleagues and/or other areas of the company are } \\
\text { hampered for me. }\end{array}$ & 0.24 & 0.54 & 1.8 \\
\hline 13. I am continually interrupted when I try to speak. & 0.27 & 0.60 & 2.4 \\
\hline 14. I feel that I am prevented from expressing myself. & 0.29 & 0.61 & 2.5 \\
\hline 15. I am verbally attacked with criticism about the work I do. & 0.33 & 0.66 & 3.6 \\
\hline $\begin{array}{l}\text { 16. I am avoided or rejected at work (avoiding visual contact, by means of scowls of explicit } \\
\text { rejection, scorn or contempt, etc.) }\end{array}$ & 0.33 & 0.71 & 4.4 \\
\hline 17. My presence is ignored, for example, exclusively addressing others (as if I did not exist). & 0.28 & 0.65 & 4.1 \\
\hline 18. New jobs are unceasingly assigned to me. & 0.42 & 0.76 & 5.1 \\
\hline $\begin{array}{l}\text { 19. The work or activities given to me require more experience than that which I possess, and } \\
\text { they are assigned to me with the intention of discrediting me. }\end{array}$ & 0.21 & 0.51 & 1.3 \\
\hline 20. I am criticized in my work in such a way that I now doubt my capacity to do my job well. & 0.22 & 0.53 & 1.9 \\
\hline $\begin{array}{l}\text { 21. I have fewer opportunities for training and for preparing myself adequately than those that } \\
\text { are offered to other colleagues. }\end{array}$ & 0.29 & 0.66 & 2.5 \\
\hline $\begin{array}{l}\text { 22. Any opportunities that I may have for a promotion or improvement in my work are blocked } \\
\text { or impeded. }\end{array}$ & 0.23 & 0.57 & 2.2 \\
\hline
\end{tabular}

†Frequency for column (A) was asked using a five-point Likert-type option: "never" (0), "almost never" (1), "sometimes" (2), "frequently" (3), and "very frequently" (4). "The relative frequency of experiencing compared with their colleagues for the column (B) was asked using three response options and dichotomized: less than my colleagues [0), same as my colleagues (0), and more than my colleagues (1).

continuous work demands. A series of confirmatory factor analyses revealed that neither the one-factor structure (GFI 0.736, AGFI 0.680, RMSEA 0.130, and AIC 6648.5) or the three-factor structure (GFI 0.791, AGFI 0.744, RMSEA 0.117, and AIC 5360.3) fit well, while the latter fit slightly better than the former.

Sex and age distribution of psychological violence and harassment at work

No significant sex difference was found in prevalence of psychological harassment at work or presence or intensity of psychological violence at work $(p>0.05$,
Table 3). Older respondents had a greater prevalence of psychological harassment at work and presence and intensity of psychological violence at work $(p<0.01)$.

\section{Comparison with other scales}

The prevalence of psychological harassment at work based on the IVAPT definition (medium or high) was $5.9 \%$, while the prevalences of workplace bullying based on the LIPT and NAQ-R were $4.1 \%$ and $9.5 \%$, respectively (Table 4 ). Presence of psychological violence was not concordant with LIPT and NAQ-R workplace bullying; for instance, only less 
Table 2. Matrix of factorial loads of the item factor analysis of the column (A) responses of the Inventory of Violence and Psychological Harassment (IVAPT) using principal components and varimax rotation $(n=1,810)^{*}$

\begin{tabular}{|c|c|c|c|}
\hline & Factor 1 & Factor 2 & Factor 3 \\
\hline 17. My presence is ignored, for example, exclusively addressing others (as if I did not exist). & 0.758 & 0.405 & 0.090 \\
\hline 13. I am continually interrupted when I try to speak. & 0.727 & 0.343 & 0.320 \\
\hline $\begin{array}{l}\text { 16. I am avoided or rejected at work (avoiding visual contact, by means of scowls of explicit } \\
\text { rejection, scorn or contempt, etc.) }\end{array}$ & 0.727 & 0.459 & 0.109 \\
\hline 14. I feel that I am prevented from expressing myself. & 0.706 & 0.342 & 0.378 \\
\hline $\begin{array}{l}\text { 22. Any opportunities that I may have of a promotion for improvement in my work are } \\
\text { blocked or impeded. }\end{array}$ & 0.662 & 0.262 & 0.333 \\
\hline $\begin{array}{l}\text { 19. The work or activities given to me require more experience than that which I possess, } \\
\text { and they are assigned to me with the intention of discrediting me. }\end{array}$ & 0.661 & 0.304 & 0.458 \\
\hline 6. I am denied information that is important and necessary for me to carry out my work. & 0.660 & 0.382 & 0.347 \\
\hline $\begin{array}{l}\text { 20. I am criticized in my work in such a way that I now doubt my capacity to do my job } \\
\text { well. }\end{array}$ & 0.652 & 0.409 & 0.371 \\
\hline $\begin{array}{l}\text { 12. The possibilities of communicating with colleagues and/or other areas of the company } \\
\text { are hampered for me. }\end{array}$ & 0.645 & 0.400 & 0.387 \\
\hline $\begin{array}{l}\text { 10. My successes at work are ignored and maliciously attributed to other people or to for- } \\
\text { eign elements such as coincidence, luck, the market situation, etc. }\end{array}$ & 0.642 & 0.510 & 0.235 \\
\hline $\begin{array}{l}\text { 7. Work situations are manipulated to make me commit errors and later accuse me of negli- } \\
\text { gence or of being a bad worker. }\end{array}$ & 0.623 & 0.465 & 0.186 \\
\hline 5. I am ignored or excluded from work meetings or from decision-making. & 0.616 & 0.341 & 0.369 \\
\hline $\begin{array}{l}\text { 21. I have fewer opportunities for training and for preparing myself adequately than those } \\
\text { that are offered to other colleagues. }\end{array}$ & 0.581 & 0.220 & 0.498 \\
\hline 15. I am verbally attacked with criticism about the work I do. & 0.571 & 0.537 & 0.342 \\
\hline 2. They have tried to humiliate me or to make a fool of me in public. & 0.346 & 0.797 & 0.287 \\
\hline 1. I receive attacks on my reputation. & 0.347 & 0.795 & 0.275 \\
\hline 3. I receive mockery, slander or public defamation. & 0.326 & 0.784 & 0.287 \\
\hline 8. Malicious or slanderous rumors are spread by the company about me. & 0.445 & 0.721 & 0.147 \\
\hline $\begin{array}{l}\text { 11. My errors or small faults are punished much more drastically than the rest of my col- } \\
\text { leagues. }\end{array}$ & 0.487 & 0.590 & 0.362 \\
\hline 9. My work is devalued and they never recognize my doing something well. & 0.475 & 0.544 & 0.374 \\
\hline $\begin{array}{l}\text { 4. They assign me work or projects with such short deadlines that they are impossible to } \\
\text { fulfill. }\end{array}$ & 0.229 & 0.266 & $\mathbf{0 . 8 3 0}$ \\
\hline 18. New jobs are unceasingly assigned to me. & 0.281 & 0.247 & 0.805 \\
\hline
\end{tabular}

* The number of factors was predetermined as three. Factor loadings greater than 0.5 are highlighted by bold.

than one-quarter of respondents were classified as experiencing LIPT or NAQ-R workplace bullying among respondents with high presence of psychological violence. On the other hand, more than $75 \%$ of respondents with high intensity of psychological violence were classified as experiencing LIPT or NAQ-R workplace bullying. While about $75 \%$ of respondents with psychological harassment at work were classified as experiencing NAQ-R workplace bullying, only less than half of them were classified as experiencing LIPT workplace bullying. The concordance measured by using kappa was 0.45 (standard error [SE], 0.04) between the IVAPT definition of psychological harassment at work (medium or high) and NAQ-R workplace bullying; it was 0.30 (SE,
0.05) between psychological harassment at work and LIPT workplace bullying.

\section{Discussion}

The Japanese version of the IVAPT showed high internal consistency reliability according to Cronbach's alpha coefficients for the total sample and for both sexes. This finding is consistent with previous studies that also showed high internal consistency of the IVAPT (0.91-0.95 in Cronbach's alpha) in Mexico, Spain, and Chile ${ }^{13,21,22)}$. The internal consistency reliability was also similar to that for the Japanese version of the NAQ-R (Cronbach's alpha of $0.91-0.95)^{20)}$.

The exploratory factor analysis showed that the 
Table 3. Prevalence of presence and intensity of psychological violence and psychological harassment assessed by the Inventory of Violence and Psychological Harassment (IVAPT) among the total respondents $(n=1,810)$ from civil servants in Japan

\begin{tabular}{|c|c|c|c|c|c|c|c|c|c|c|c|c|}
\hline & \multirow{2}{*}{\multicolumn{2}{|c|}{ Total $(n=1,810)$}} & \multicolumn{4}{|c|}{ Sex } & \multicolumn{6}{|c|}{ Age group } \\
\hline & & & \multicolumn{2}{|c|}{ Men $(n=909)$} & \multicolumn{2}{|c|}{ Women $(\mathrm{n}=901)$} & \multicolumn{2}{|c|}{$20-34(n=473)$} & \multicolumn{2}{|c|}{$35-49(n=788)$} & \multicolumn{2}{|c|}{$50-63(n=549)$} \\
\hline & $\mathrm{n}$ & $(\%)$ & $\mathrm{n}$ & $(\%)$ & $\mathrm{n}$ & $(\%)$ & $\mathrm{n}$ & $(\%)$ & $\mathrm{n}$ & $(\%)$ & $\mathrm{n}$ & $(\%)$ \\
\hline \multicolumn{13}{|c|}{ Presence of psychological violence } \\
\hline High & 556 & $(30.7 \%)$ & 260 & $(28.6 \%)$ & 296 & $(32.9 \%)$ & 117 & $(24.7 \%)$ & 239 & $(30.3 \%)$ & 200 & $(36.4 \%)$ \\
\hline Medium & 308 & $(17.0 \%)$ & 153 & $(16.8 \%)$ & 155 & $(17.2 \%)$ & 112 & $(23.7 \%)$ & 129 & $(16.4 \%)$ & 67 & $(12.2 \%)$ \\
\hline \multirow[t]{2}{*}{ None } & 946 & $(52.3 \%)$ & 496 & $(54.6 \%)$ & 450 & $(49.9 \%)$ & 244 & $(51.6 \%)$ & 420 & $(53.3 \%)$ & 282 & $(51.4 \%)$ \\
\hline & & & \multicolumn{4}{|c|}{$p=0.103(\mathrm{df}=2)$} & & & \multicolumn{2}{|c|}{$p<0.001(\mathrm{df}=4)$} & & \\
\hline \multicolumn{13}{|c|}{ Intensity of psychological violence } \\
\hline High & 21 & $(1.2 \%)$ & 13 & $(1.4 \%)$ & 8 & $(0.9 \%)$ & 1 & $(0.2 \%)$ & 8 & $(1.0 \%)$ & 12 & $(2.2 \%)$ \\
\hline Medium & 137 & $(7.6 \%)$ & 66 & $(7.3 \%)$ & 71 & $(7.9 \%)$ & 28 & $(5.9 \%)$ & 55 & $(7.0 \%)$ & 54 & $(9.8 \%)$ \\
\hline Low & 706 & $(39.0 \%)$ & 334 & $(36.7 \%)$ & 372 & $(41.3 \%)$ & 200 & $(42.3 \%)$ & 305 & $(38.7 \%)$ & 201 & $(36.6 \%)$ \\
\hline \multirow[t]{2}{*}{ None } & 946 & $(52.3 \%)$ & 496 & $(54.6 \%)$ & 450 & $(49.9 \%)$ & 244 & $(51.6 \%)$ & 420 & $(53.3 \%)$ & 282 & $(51.4 \%)$ \\
\hline & & & \multicolumn{4}{|c|}{$p=0.132(\mathrm{df}=3)$} & & & \multicolumn{2}{|c|}{$p=0.009(\mathrm{df}=6)$} & & \\
\hline \multicolumn{13}{|c|}{ Psychological harassment at work } \\
\hline High & 49 & $(2.7 \%)$ & 21 & $(2.3 \%)$ & 28 & $(3.1 \%)$ & 5 & $(1.1 \%)$ & 22 & $(2.8 \%)$ & 22 & $(4.0 \%)$ \\
\hline Medium & 58 & $(3.2 \%)$ & 24 & $(2.6 \%)$ & 34 & $(3.8 \%)$ & 21 & $(4.4 \%)$ & 28 & $(3.6 \%)$ & 9 & $(1.6 \%)$ \\
\hline \multirow[t]{2}{*}{ None } & 1,703 & $(94.1 \%)$ & 864 & $(95.0 \%)$ & 839 & $(93.1 \%)$ & 447 & $(94.5 \%)$ & 738 & $(93.7 \%)$ & 518 & $(94.4 \%)$ \\
\hline & & & \multicolumn{4}{|c|}{$p=0.217(\mathrm{df}=2)$} & \multicolumn{6}{|c|}{$p=0.005(\mathrm{df}=4)$} \\
\hline
\end{tabular}

Table 4. Proportion (\%) of workplace bullying according to the Leymann Inventory of Psychological Terrorization (LIPT) and the Negative Acts Questionnaire-Revised (NAQ-R) by the Inventory of Violence and Psychological Harassment (IVAPT) classifications $^{\dagger}$

\begin{tabular}{|c|c|c|c|c|c|c|}
\hline & \multicolumn{3}{|c|}{ LIPT } & \multicolumn{3}{|c|}{ NAQ-R } \\
\hline & Total $n$ & $\mathrm{n}$ & $(\%)$ & Total $n$ & $\mathrm{n}$ & $(\%)$ \\
\hline Total sample & 1,744 & 72 & $4.1 \%$ & 1,762 & 167 & $9.5 \%$ \\
\hline \multicolumn{7}{|c|}{ IVAPT Presence of psychological violence } \\
\hline High & 521 & 51 & $9.8 \%$ & 540 & 131 & $24.3 \%$ \\
\hline Medium & 298 & 10 & $3.4 \%$ & 299 & 19 & $6.4 \%$ \\
\hline \multirow[t]{2}{*}{ None } & 925 & 11 & $1.2 \%$ & 923 & 17 & $1.8 \%$ \\
\hline & \multicolumn{3}{|c|}{$p<0.001(\mathrm{df}=2)$} & \multicolumn{3}{|c|}{$p<0.001(\mathrm{df}=2)$} \\
\hline
\end{tabular}

IVAPT Intensity of psychological violence

\begin{tabular}{lrrrrrr} 
High & 21 & 16 & $76.2 \%$ & 21 & 21 & $100.0 \%$ \\
Medium & 127 & 15 & $11.8 \%$ & 132 & 56 & $42.4 \%$ \\
Low & 671 & 30 & $4.5 \%$ & 686 & 73 & $10.6 \%$ \\
None & 925 & 11 & $1.2 \%$ & 923 & 17 & $1.8 \%$ \\
& \multicolumn{2}{c}{$p<0.001(\mathrm{df}=3)$} & & $p<0.001(\mathrm{df}=3)$
\end{tabular}

IVAPT Psychological harassment at work

\begin{tabular}{lrrrrrr} 
High & 48 & 21 & $43.8 \%$ & 49 & 37 & $75.5 \%$ \\
Medium & 54 & 8 & $14.8 \%$ & 57 & 30 & $52.6 \%$ \\
None & 1,642 & 43 & $2.6 \%$ & 1,656 & 100 & $6.0 \%$ \\
& \multicolumn{2}{c}{$p<0.001(\mathrm{df}=2)$} & \multicolumn{2}{c}{$p<0.001(\mathrm{df}=2)$}
\end{tabular}

Case definitions: Exposure to at least one form of bullying within the previous 12 months, weekly or more, and for at least six months for the LIPT; a total score of 45 or over for the NAQ-R. 
first factor explained a large proportion of the variance $(64.5 \%)$, suggesting that the scale measures a unidimensional construct. This finding is consistent with previous reports that $53-66 \%$ of the variance was explained by the first factor in Mexico, Spain and Chile $^{13,21,22)}$. However, the previous study also reported that a one-factor structure or three-factor structure did not fit the data very well based on the results of the confirmatory factor analyses, while the three-factor structure observed in the Spanish version did slightly better ${ }^{13)}$. The three-factor structure extracted by the exploratory factor analysis in this sample was similar to that observed in the Spanish version to some extent. There were two major factors related to (1) both manipulation to induce punishment and obstacles to work performance (item \#5-7, 12-17 and 19-22) and (2) damage to public image (item \#1-3, 8-11 and 15) and obstacles to work performance, which are similar to the factor structure observed in the Spanish version $^{13)}$, while some items were loaded differently. A particularly unique feature of the factor structure in this sample was that the third factor seems to represent a separate factor for too many job demands as a form of psychological violence. This may be a unique feature of psychological violence/harassment at work in Japan.

The prevalence of presence (medium or high) of psychological violence was $47.8 \%$ in this sample, which was much lower than those in other studies (83.3\% in Chile, $86.3 \%$ in Mexico, and $86.2 \%$ in Spain) ${ }^{13)}$. The prevalence of intense (medium or high) of psychological violence was $8.8 \%$, which is similar to that in Mexico $(10.5 \%)$ but much lower than that in Spain $(20.5 \%)$ or Chile $(39.5 \%)$. The prevalence (medium or high) of psychological harassment at work was $5.9 \%$, which was lower than previous reports in Mexico (8.5\%), Chile (17.9\%), and Spain (9.4\%). In this study, there was no significant difference among sex in any of these prevalences, which is similar to previous results of Aldrete et al. ${ }^{29)}$ and Pando et $a l .{ }^{21)}$ but inconsistent with those of Hirigoyen ${ }^{30)}$ and Chiaroni and Chiaroni ${ }^{31)}$. We found that older respondents reported a higher prevalence.

The prevalence of psychological harassment at work based on the IVAPT definition (high or medium) $(5.9 \%)$ was higher than the prevalence $(4.1 \%)$ based on the LIPT but lower than that $(9.5 \%)$ based on the NAQ-R. This is almost consistent with previous studies using these three instruments. The LIPT seems to measure a more severe psychological harassment at work, and the NAQ-R seems to measure a milder one than the IVAPT. All three indicators based on the IVAPT were statistically associated with workplace bullying based on the LIPT and NAQ-R, suggesting concurrent validity of the IVAPT compared with these two scales. More interestingly, the high intensity of psychological violence was strongly associated with LIPT and NAQ-R workplace bullying. There was a greater concordance between the IVAPT definition of psychological harassment at work and NAQ-R workplace bullying than between the IVAPT and LIPT. It is suggested that the construct measured by the IVAPT is more close to that measured by the NAQ-R. Both LIPT and NAQ-R may be sensitive for measurement of psychological violence, since when psychological violence becomes severe, it would increase the risk of psychological harassment at work as well. But the LIPT may be less sensitive for measurement of psychological harassment at work. These findings could be useful in classifying existing scales of psychological harassment at work and comparison of findings based on different scales.

\section{Limitations}

Several limitations should be noted. First, the response rate was not high. Also, there were many respondents who failed to fill in column (B). The results may be biased toward those who were willing to report their experience of psychological violence and harassment at work. While we assigned a neutral value (same as one's colleagues) to the respondents who reported "never" in column (A), which we consider reasonable, a better way to impute missing responses in column (B) may need to be developed. Second, the sample was from civil servants, particularly from nonmanual workers. The results may reflect more characteristics of the sample. A replication study is needed among blue-collar workers and in private sectors. While we used the original criteria to define psychological violence and harassment at work based on the IVAPT, the cut-off may vary from country to country. Also, while it sounds reasonable to differentiate psychological violence and psychological harassment at work based on the IVAPT, evidence for the classification is still not available in Japan. A further study should be conducted to rationalize the classification by, for example, comparing psychological impacts of psychological violence, and psychological harassment at work.

Even with these limitations, the present study has shown that the Japanese version of the IVAPT is a reliable and valid instrument for measurement of psychological violence and harassment at work. The instrument could be useful in international comparison studies of psychological violence and harassment at work between Latin American countries and Japan, as well as other countries, and in studies intending to differentiate psychological violence and harassment at work. 
Acknowledgments: The present study was supported by the 2009 Occupational Health Research Fund from the Occupational Health Promotion Foundation, Japan.

\section{References}

1) Leymann H. The content and development of mobbing at work. Eur J Work Organ Psychol 1996; 5: 165-84.

2) Einarsen S, Hoel H, Zapf D, Cooper CL. The concept of bullying at work. In: Einarsen S, Hoel H, Zapf D, Cooper CL, editors. Bullying and emotional abuse in the workplace: international perspectives in research and practice. London (UK): Taylor \& Francis; 2003. p.3-30.

3) Moreno-Jiménez B, Rodríguez-Muñoz A, Morante ME, Garrosa E, Rodríguez-Carvajal R, Díaz-Gracia L. Evaluación del acoso psicológico en el trabajo: desarrollo y estudio exploratorio de una escala de medida [Assessment of bullying at work: development and exploratory study of a measurement scale]. Univ Psychol 2008; 7: 335-45 (in Spanish).

4) Hoel H, Sparks K, Cooper CL. The cost of violence/ stress at work and the benefits of a violence/stressfree working environment. Geneva (Switzerland): International Labour Organiaztion. [Online]. 2001 [cited 2012 Sept 17]; Available from: http://www.ilo. org/wcmsp5/groups/public/---ed_protect/---protrav/--safework/documents/publication/wcms_108532.pdf

5) Parent-Thirion A, Vermeylen G, van Houten G, Lyly-Yrjänäinen M, Biletta I, Cabrita J. Fifth European Working Conditions Survey-Overview report. Eurofound (Ireland); 2012.

6) Merllié D, Paoli P. Ten years of working conditions in the European Union. Luxembourg, Office for Official Publications of the European Communities/ European Foundation for the Improvement of Living and Working Conditions, 2000. p. 7.

7) Leymann H, Gustafsson A. Mobbing at work and the development of posttraumatic stress disorders. Eur J Work Organ Psychol 1996; 5: 251-75.

8) Mikkelsen EG, Einarsen S. Bullying in Danish work-life: prevalence and health correlates. Eur J Work Organ Psychol 2001; 10: 393-413.

9) Pando Moreno M, Aranda C, Torres TM, Salazar JG. Trastornos de sueño asociados a la violencia genérica en el trabajo y el mobbing [Sleep disorders associated with generic violence and workplace mobbing]. Revista Ciencia y Trabajo 2010; 12: 267-71 (in Spanish).

10) Takaki J, Taniguchi T, Fukuoka E, et al. Workplace bullying could play important roles in the relationships between job strain and symptoms of depression and sleep disturbance. J Occup Health 2010; 52: 367-74.

11) Tehrani N. Bullying: a source of chronic posttraumatic stress? Br J Guid Counsell 2004; 32: 357-66.

12) Vartia M. The sources of bullying-psychological work environment and organizational climate. Eur J Work Organ Psychol 1996; 5: 203-14.
13) Carrión GMA, López BF, Pando MM. Inventario de Violencia y Acoso Psicologico en el Trabajo IVAPT-E-R [Inventory of Violence and Bullying at Work, IVAPT-ER]. Barcelona (Spain): Asociación de Expertos en Psicosociología Aplicada (AEPA); 2007 (in Spanish).

14) Leymann H. The content and development of mobbing at work. Eur J Work Organ Psychol 1996; 5: $165-84$.

15) Leymann H. Mobbing and psychological terror at workplaces. Viol Victims 1990; 5: 119-26.

16) Einarsen S, Raknes B. Harassment in the workplace and the victimization of man. Viol Victims 1997; 12: 247-63.

17) Martínez-Lugo M. El acoso psicológico en el trabajo: la experiencia en Puerto Rico [Psychological harassment at work: the experience in Puerto Rico]. Aletheia 2006; 24: 21-33 (in Spanish).

18) Nielsen MB, Skogstad A, Matthiesen SB, et al. Prevalence of workplace bullying in Norway: comparisons across time and estimation methods. Eur J Work Organ Psychol 2009; 18: 81-101.

19) Zapf D, Einarsen S, Hoel H, Vartia M. Empirical findings on bullying in the workplace. In: Einarsen S, Hoel H, Zapf D, Cooper CL, editors. Bullying and emotional abuse in the workplace: international perspectives in research and practice. London (UK): Taylor \& Francis; 2003. p.103-26.

20) Tsuno K, Kawakami N, Inoue A, Abe K. Measuring workplace bullying: reliability and validity of the Japanese version of the Negative Acts Questionnaire. J Occup Health 2010; 52: 216-26.

21) Pando M, Aranda C, Preciado L, Franco S, Salazar J. Validez y Confiabilidad del Inventario de Violencia y Acoso Psicológico en el Trabajo (IVAPT) [Validity and reliability of the Inventory of Violence and Bullying at Work (IVAPT)]. Enseñanza e Investigación en Psicología 2006; 11: 319-32 (in Spanish).

22) Macía SF. Aplicación y evaluación psicométrica del test IVAPT en dos centros de atención primaria [Implementation and evaluation IVAPT psychometric test in two primary care centers]. Psicología y Salud 2008; 18: 247-54 (in Spanish).

23) Pando Moreno M, López Palomar MR, García Cueva SA, Ochoa Zavala H, Rodríguez López EM. Prevalence of mobbing in workers of Costa Rica. Int J Hispanic Psychol 2010; 3: 15-24.

24) Pando M, Aranda C, Álvarez M. Análisis factorial exploratorio confirmatorio del Inventario de Violencia y Acoso Psicológico en el Trabajo (IVAPT) para Bolivia y Ecuador [Confirmatory factor analysis of the Inventory of Violence and Bullying at Work (IVAPT) for Bolivia and Ecuador]. Revista Liberabit 2012; 18: 27-36 (in Spanish).

25) Pando $M$, Bertot $M$, Aranda $C$, Amezcua MT. Análisis factorial exploratorio del Inventario de Violencia y Acoso Psicológico en el Trabajo (IVAPT) para Cuba [Exploratory factor analysis of the Inventory of Violence and Bullying at Work (IVAPT) 
to Cuba]. Revista Mexicana de Salud en el Trabaj 2011; 1: 8-14 (in Spanish).

26) Monaco E, Bianco G, Di Simione, Di Giuseppe B, Prestigiacomo C. Patologie emergente in medicina del lavoro: il mobbing [Emerging diseases in occupational medicine: bullying]. G Ital Med Lav Ergon 2004; 26: 28-32 (in Italian).

27) Wolfberg E. Crisis social y desgaste ocupacional de los profesionales de la salud: alertas y recursos [Social crisis and wear occupational health professionals: alerts and resources]. Vertex 2003; 14: 268-79 (in Spanish).

28) Einarsen S, Hoel H. The Negative Acts Questionnaire: development, validation and revision of a measure of bullying at work. Paper presented at the 10th European Congress on Work and Organisational Psychology. Prague (Czech Republic): 10th European Congress on Work and
Organizational Psychology; 2001

29) Aldrete RMG, Pando MM, Aranda BC, Torres LTM. Acoso psicológico en el trabajo ¿Un problema de Genero? [Psychological harassment at work. A gender issue?] Enseñanza e investigación en psicología 2006; 11: 53-63.

30) Hirigoyen M. El acoso moral en el trabajo. Distinguir lo verdadero de lo falso [Bullying at work. Distinguish the true from the false]. Barcelona (Spain): Editorial Paidós; 2001 (in Spanish).

31) Chiaroni J, Chiaroni P. Dones épidémiologiques des situations de mobbing d'après une enquête effectuée auprès des medecins du travail en region PACA un profil type du salarié harcelé [The epidemiological situations of bullying from a survey of doctors working in the area PACA profile type harassed employee]. Archives des Maladies Professionnelles 2001; 2: 96-107 (in French).

\section{Apendix. INVENTORY OF VIOLENCE AND PSYCHOLOGICAL HARASSMENT AT WORK (IVAPT)}

The questionnaire that you are about to answer is given to you with the intention of getting to know some aspects of the psychological relationships in the workplace. For this purpose, you are required to answer the questions by means of the two columns. The first, which is column (A), refers to the frequency with which the item being asked occurs, and the second (B) alludes to the frequency with which the item occurs with respect to your colleagues.

\section{ANSWERS:}

A)

4. Very frequently

3. Frequently

2. Sometimes

1. Almost never

0 . Never
B)

1. Less than my colleagues

2. The same as my colleagues

3. More than the rest of my colleagues

\begin{tabular}{|c|c|c|}
\hline QUESTIONS & A & $\mathrm{B}$ \\
\hline 1. I receive attacks on my reputation. & & \\
\hline 2. They have tried to humiliate me or to make a fool of me in public. & & \\
\hline 3. I receive mockery, slander or public defamation. & & \\
\hline 4. They assign me work or projects with such short deadlines that they are impossible to fulfill. & & \\
\hline 5. I am ignored or excluded from work meetings or from decision-making. & & \\
\hline 6. I am denied information that is important and necessary for me to carry out my work. & & \\
\hline $\begin{array}{l}\text { 7. Work situations are manipulated to make me commit errors and later accuse me of negligence or of being a } \\
\text { bad worker. }\end{array}$ & & \\
\hline 8. Malicious or slanderous rumors are spread by the company about me. & & \\
\hline 9. My work is devalued and they never recognize my doing something well. & & \\
\hline $\begin{array}{l}\text { 10. My successes at work are ignored and maliciously attributed to other people or to foreign elements such as } \\
\text { coincidence, luck, the market situation, etc. }\end{array}$ & & \\
\hline 11. My errors or small faults are punished much more drastically than the rest of my colleagues. & & \\
\hline 12. The possibilities of communicating with colleagues and/or other areas of the company are hampered for me. & & \\
\hline
\end{tabular}




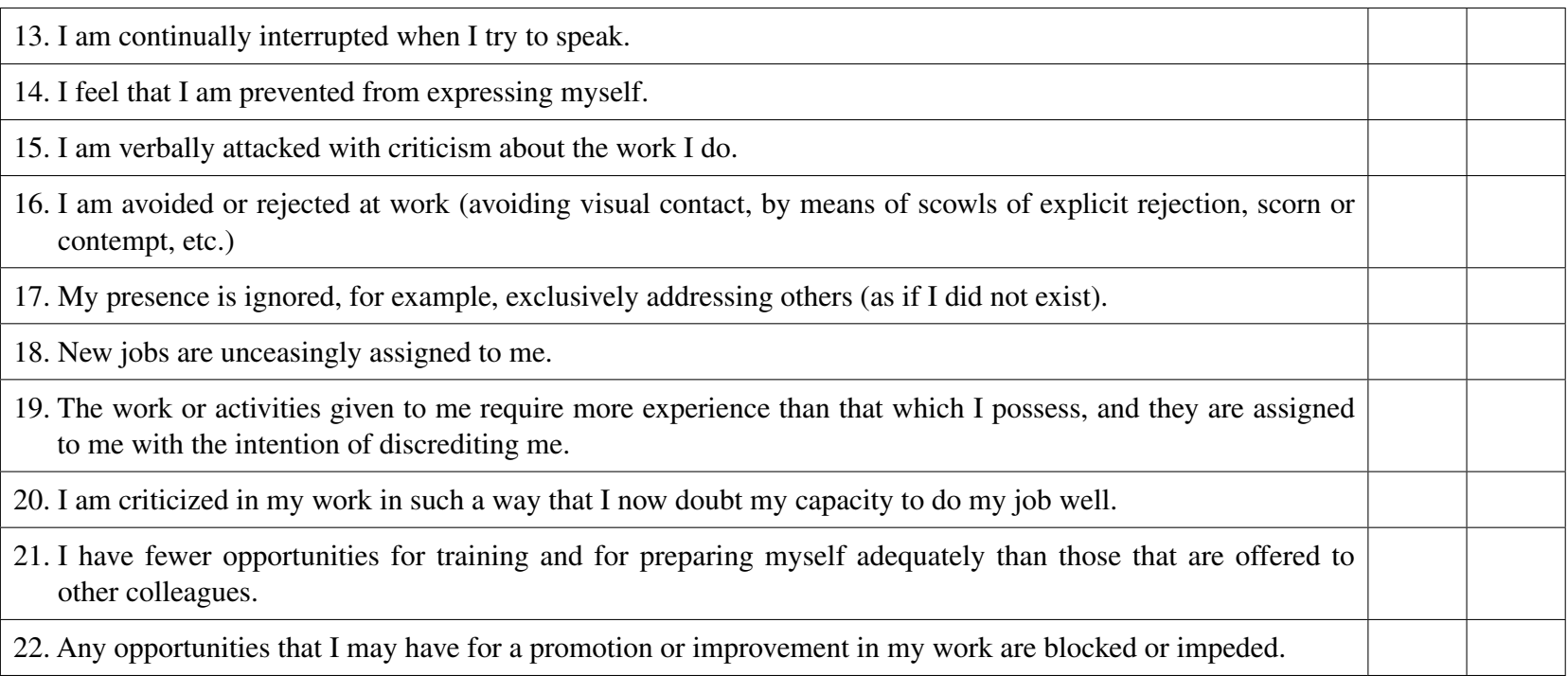

*The people who produce the above-mentioned in me (are):

My boss or bosses

My work colleague(s)

My subordinate(s)

IVAPT-PANDO 尺度（職場における心理的暴力・嫌がらせ尺度）日本語版

この調査票は，職場での人間関係について調べるためのものです。個人の体験と，その体験の頻度を同僚と比較し た場合を，分けて調査します，各質問において A 欄にはご自分が経験した頻度を，B欄には同僚と比べた場合の頻度を， それぞれの回答選択肢の番号で答えて下さい（それぞれの回答選択肢の番号に○をつけてください）.

\begin{tabular}{|l|l|l|}
\hline 回答選択肢 & A. 自分が経験した頻度 & B. 同僚と比べて \\
& 0. まったくない & 1. 同僚よりも少ない \\
& 1. ほとんどない & 2. 同僚と同じくらい \\
& 2. 時々ある & 3. 同僚よりも多い \\
& 3. よくある & \\
& 4. 非常によくある & \\
\hline
\end{tabular}

\begin{tabular}{|c|c|c|}
\hline 質問 & $\begin{array}{c}\mathrm{A} \\
\text { 自分が経験した } \\
\text { 頻度 }\end{array}$ & $\begin{array}{c}\mathrm{B} \\
\text { 同僚と } \\
\text { 比べて }\end{array}$ \\
\hline 1. 自分の評判を傷つけるような攻撃を受ける. & $\begin{array}{lllll}0 & 1 & 2 & 3 & 4\end{array}$ & 123 \\
\hline 2. 人前で屈辱を与えられたり, 馬鹿にされそうになる. & $\begin{array}{lllll}0 & 1 & 2 & 3 & 4\end{array}$ & 123 \\
\hline 3. 皆の前で, 悪口を言われたり，からかわれたり，中傷されたりする. & $\begin{array}{lllll}0 & 1 & 2 & 3 & 4\end{array}$ & 123 \\
\hline 4. 実行が不可能な短い期間で, 仕事やプロジェクトを行なうよう命じられる. & 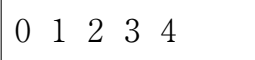 & 123 \\
\hline 5. 職場の会合や意思決定について連絡されなかったり，その場からはずされたりする. & $\begin{array}{lllll}0 & 1 & 2 & 3 & 4\end{array}$ & 123 \\
\hline 6. 自分の仕事に必要な, 大事な情報を得るのを邪魔される. & $\begin{array}{lllll}0 & 1 & 2 & 3 & 4\end{array}$ & 123 \\
\hline $\begin{array}{l}\text { 7. 職場内で, 自分がミスをするようにあらかじめ仕組まれており, 実際にミスをす } \\
\text { ると, そのことを怠慢であるとか, 仕事ができないなどと非難される. }\end{array}$ & $\begin{array}{lllll}0 & 1 & 2 & 3 & 4\end{array}$ & 123 \\
\hline
\end{tabular}




\begin{tabular}{|c|c|c|}
\hline 8. 会社の中で, 自分について悪意あるうわさや中傷する内容を広められる. & $\begin{array}{lllll}0 & 1 & 2 & 3 & 4\end{array}$ & 123 \\
\hline $\begin{array}{l}\text { 9. 自分の仕事ぶりが低く評価され，よくやったことについても決してそれを認めて } \\
\text { もらえない. }\end{array}$ & $\begin{array}{lllll}0 & 1 & 2 & 3 & 4\end{array}$ & 123 \\
\hline $\begin{array}{l}\text { 10. 自分の仕事上の成功は無視され，悪意を持って，他の人の手柄にされたり，偶然 } \\
\text { や幸運，市場の状況などの扔かげだと言われる. }\end{array}$ & $\begin{array}{lllll}0 & 1 & 2 & 3 & 4\end{array}$ & 123 \\
\hline 11. 自分のミスや小さな失敗は, 必要以上に厳しく罰せられる. & $\begin{array}{lllll}0 & 1 & 2 & 3 & 4\end{array}$ & 123 \\
\hline 12. 同僚や他の職場の人と話したり, 相談したりするのを妨害される. & $\begin{array}{lllll}0 & 1 & 2 & 3 & 4\end{array}$ & 123 \\
\hline 13. 自分が話をしようとすると，常にそれをさえぎられる. & $\begin{array}{lllll}0 & 1 & 2 & 3 & 4\end{array}$ & 123 \\
\hline 14. 自分が意見を言おうとすると邪魔される. & 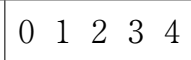 & 123 \\
\hline 15. 自分がしている仕事を批判されたり，言葉で攻撃される. & $\begin{array}{lllll}0 & 1 & 2 & 3 & 4\end{array}$ & 123 \\
\hline $\begin{array}{l}\text { 16. 仕事中に避けたられたり，拒否されたりする（目を合わせない，あからさまな拒 } \\
\text { 絶の身振りや無関心な態度をとる, あるいは見下した態度をとる, などによって）. }\end{array}$ & $\begin{array}{lllll}0 & 1 & 2 & 3 & 4\end{array}$ & 123 \\
\hline $\begin{array}{l}\text { 17. 自分の存在を無視される. 例えば自分が見えない，あるいは存在しないかのよう } \\
\text { に，他の人にばかりに話しかける. }\end{array}$ & $\begin{array}{lllll}0 & 1 & 2 & 3 & 4\end{array}$ & 123 \\
\hline 18. 終わらないうちに, 次から次へと新しい仕事を割り当てられる. & 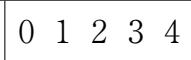 & 123 \\
\hline $\begin{array}{l}\text { 19. 信用を失わせようとして, 自分の能力を超える経験を必要とする仕事をわりあて } \\
\text { られる. }\end{array}$ & $\begin{array}{lllll}0 & 1 & 2 & 3 & 4\end{array}$ & 123 \\
\hline $\begin{array}{l}\text { 20. 業務をやりとげる能力に, 自分自身で疑いをもつように仕向けるような批判をさ } \\
\text { れる. }\end{array}$ & $\begin{array}{lllll}0 & 1 & 2 & 3 & 4\end{array}$ & 123 \\
\hline 21. 教育や訓練を受ける機会を与えてもらえない. & $\begin{array}{lllll}0 & 1 & 2 & 3 & 4\end{array}$ & 123 \\
\hline $\begin{array}{l}\text { 22. 昇進したり，よりよい条件で働けるようになる機会を，奪われたり，邪魔された } \\
\text { りしている. }\end{array}$ & $\begin{array}{lllll}0 & 1 & 2 & 3 & 4\end{array}$ & 123 \\
\hline
\end{tabular}

上記で，いずれかを経験したことがあると回答された方のみ，以下の質問にお答えください．

上記のことをあなたに行っている（行っていそうな）人は，誰ですか．あてはまる番号にいくつでも○をつけてくだ さい.

1. 自分の上司（たち） $\quad$ 2. 職場の同僚（たち） 3. 部下（たち）

4. その他の人（たち）（どんな関倸の人ですか?

（注：上の項目ごとに行なった人が異なる場合，行ったことのある人すべてに○をつけてください） 